\title{
The Contributing Effects of Human Activities to Flooding in Ota, Ogun State
}

\author{
Oseni A. E. ${ }^{1, *}$ and Bamidele E. T. ${ }^{2}$ \\ ${ }^{1,2}$ Department of Surveying and Geoinformatics, Bells University of Technology, Ota, Ogun State, Nigeria \\ Corresponding Author: *ayo_oseni@yahoo.com
}

https://doi.org/10.36263/nijest.2020.01.0195

\begin{abstract}
Flood is considered to be a major natural disaster occurrence that affects human existence and the environment in many parts of the world. The objective of this study is to analyze the flood-prone areas and determine their spatial locations using GPS and also determine the causes of flooding in the study area through questionnaires. To achieve this, primary source data like fieldwork was used and secondary source data like administration of questionnaires was also used. A Survey of 120 randomly sampled respondents was conducted in different flood-prone locations and 100 responded. The data obtained from the questionnaires was analyzed for the determination of the flood-prone areas in Ota, Ogun State. The result reveals that human activities like the dumping of refuse in drainage, bad road network, lack of proper drainage is majorly responsible for the areas to be at risk of flood prone. It was recommended that the government should create public awareness and sensitization campaigns should be embarked on to prevent the occurrence of this hazardous event in the future.
\end{abstract}

Keywords: Flood, GPS, Data, Drainage, Refuse

\subsection{Introduction}

Flood is a hazardous type of natural disaster which is a flow of water that rises above carrying capacity of a channel. It is also defined as a large amount of water that covers an area that was usually dry (Olajuyigbe et al., 2012).

There are different occurrences of floods in Nigeria due to heavy rainfall and excess releases from dams with low capacities to cope with a high inflow of water into their reservoir areas to safe the dams whose failure could be more epidemic than the consequences of the releases, however, this can destroy houses, properties, farm produce, and animals. This natural event has caused loss of thousands of lives and millions of naira worth of properties. Flood in the cities has led to high level of water overflowing into the streets and roads, thus causing many problems like collapse of bridge, building damage and traffic problems. The risks of floods are possible to avoid and prevented from occurrence. Managing flood and other disasters focus on proper measures on reducing the socioeconomic impacts of these disasters through mobilizing relief materials with little investments into research efforts which aim at understanding the dynamics of these natural events and reducing the impacts of future flood events.

Sharma and Sharma (2000) stated that effort to control flood and its impact has led to the development of technologies for analyzing and assessment of flood and flood prone areas. New technologies such as Geographic Information Systems (GIS), measurement of rainfall, stream discharge and soil moisture by radar, remote sensing using camera and geophysical sensors from satellites and aircrafts, processing and retrieval by use of digital computers, automation of data storage, electric analogs, were employed to predict hydrology.

During a flood, agricultural crops and household items including food items, rugs, television sets, fridges, chairs, tables and other expensive electronics can be damaged when water from the river 
submerged most of the houses. Several mechanic workshops, grocery stores and pharmaceutical shops, structures like churches, mosques and private buildings can also be affected during the flood. There has been different incidence of floods and its negative effects in most of the urban centers of developing countries. For example, in Nigeria, it has been reported that terrible flood disaster had occurred in Ibadan (1985, 1987, 1990, and 2011), Osogbo (1992, 1996, 2002, and 2010), Yobe (2000), Akure (1996, 2000, 2002, 2004 and 2006) and the coastal cities of Lagos, Ogun, Port Harcourt, Calabar, Uyo, Warri among others (Olaniran, 1983). This calamity claimed many lives and properties worth millions of naira. Several anthropogenic factors have contributed to the incidence of flood. Part of these factors is the penetration of development and urbanization to flood prone areas. The encroachment into such areas has being on-going until now because of unprecedented urbanization and industrialization which has undoubtedly resulted into high rate of deforestation, loss of surface vegetation and farmlands. The unplanned and uncontrolled development, and industrialization into urban infrastructure facilities, violate the major objectives of physical planning and consequently result into misuse of land thereby creating disorderly arrangement of urban landscape and the occurrence flood that is mostly evident in cities of third world countries.

Etinosa (2006) in a discussion paper on "dams are unrenewable" reported that over 26 villages including Galadima Kogo, Gofa, Kusasun, Pai, Lagado, Nakpinda and Karai in Kede, Lakpma and Shiroro Local Government in Niger State were flooded by the waters from Rivers Niger and Kaduna. The flood which struck in the early hours of Saturday 11th September, 2003 resulted from a heavy rainfall and the release of excess water from the Shiroro Hydro-Electric Dam by the National Electric Power Authority (NEPA). The flood displaced about 10,000 persons in Ketsho in Kede Local Government, while other 13,500 persons in Lakpam and Shiroro were rendered homeless. The OgunOsun river systems on which we have Oyan and Ikere Gorge dams are characterized by annual flood occurrences, flooding Abeokuta and Lagos each year. River Benue is also not left out of flooding, washing away the bridge at Jimeta in 2005.

According to Etinosa (2006), water will always find its way if not well channeled. Its choice route often poses problems to man by tampering with his physical environment, health and products of agriculture, urbanization and industrialization. This has created a lot of social and economic cost on the environment. Few among these social and economic impacts on the environment are: outbreak of health diseases, infrastructure failure, mental health effects, building collapse, destruction of agricultural farmland and products. Flood has been reported as a major and devastating problem in some sectors of the economy (Petak and Atkisson, 1982). Its effects are very severe to virtually all forms of land use. The severity of its impact is also reflected on the rate of development of most nations that experience such. Thus if adequate attention in terms of preventive measures are not put in place towards controlling its sporadic occurrence and its associated impacts particularly during rainy season, its incidence can turn a developed nation back into a developing nation.

Many researchers have stated that flood is an overflow of an expansion of water that submerges land, The European Union (EU) Flood directive (2007), defines a flood as a temporary covering by water of land that is not normally covered by water. In the sense of "flowing water", the word may also be applied to the inflow of the tide. This water comes from the overflow of sea, lakes, rivers, canals, sewers or from rainwater. Flooding is normally caused by natural weather events such as heavy rainfall and thunderstorms over a short period, prolonged rainfall or extensive rainfall. It can also be caused by high tide combined with stormy conditions. It is predicted that climate change will increase the risk of flooding in the UK and other parts of the world (Petak and Atkisson, 1982). There is risk whenever heavy downpour of rainfall flows overland from the area it first precipitated to become runoff.

Odunuga et al. (2012) also established flood it is an unusual high stage of water usually above the bank of its flow path (artificial or manmade). When it causes damage to goods and properties or impairs human activities, it becomes a hazard. Olajuyigbe et al. (2012) stated that flood may also result from overflowing of a great body of water over land and extreme hydrological events or an unusual presence of water on land to a depth which affects normal activities. Flood occurs as a result of combination of meteorological and hydrological extremes as well as activities of man on drainage basin (Adeaga, 2008). 
The problems of areas prone to flooding in Ado-Odo Ota have been considered as the serious problems in the area especially during the raining season. This periodic flooding in Ota is a perpetual event which happens during the period of heavy rainfall in which most of the drainages exceed their normal channel capacity and frequently overflow causing loss of properties and more havoc in the community. The areas that are mostly flooded are those that lack proper channeled drainage and those that are occupied by domestic refuse.

\subsection{Methodology}

\subsection{Study area}

The study area is depicted in Figure 1, showing the Ogun State within the Nigeria federation, Figure 2, showing the Ado-Odo Ota Local Government within Ogun State, and Figure 3, showing the satellite image of the studied location within Ado-Odo Ota Local Government. The studied locations in Ado-Odo Sango-Ota Local Government include Oju-ore, Joju, and Ijoko Road. The study area, Ado-Odo Ota Local Government Area, Ogun State, is in the South Eastern part of Nigeria. It is located between the Latitude 6.611719 and the Longitude 3.05762. It borders Lagos State to the South, Oyo State and Osun State to the North, Ondo State to the East and the Republic of Benin to the West. Figure 4, therefore, shows points of data measurements for this work, in the study area.

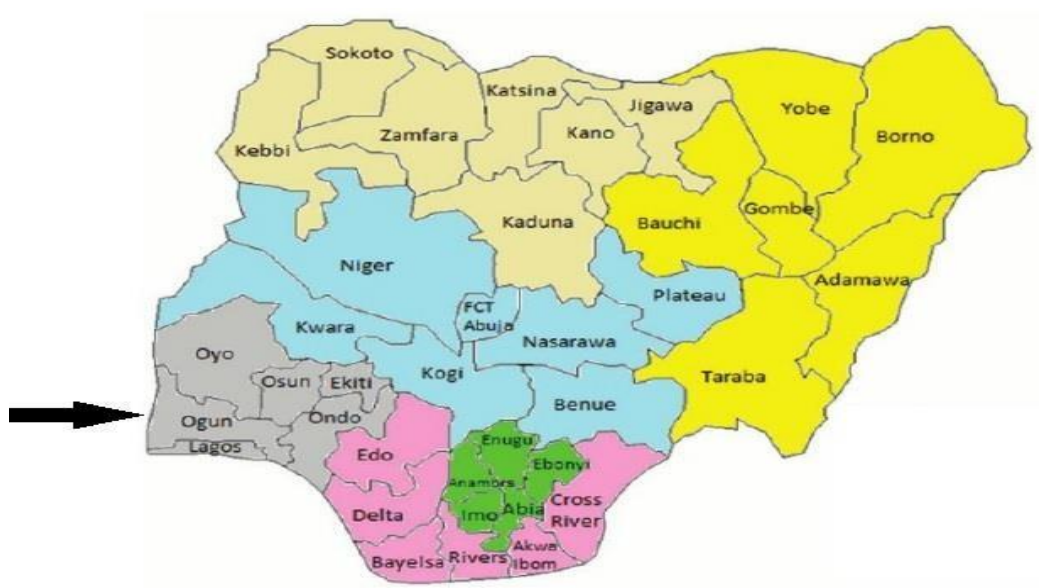

Figure 1: Map of Nigeria showing Ogun State, the study area

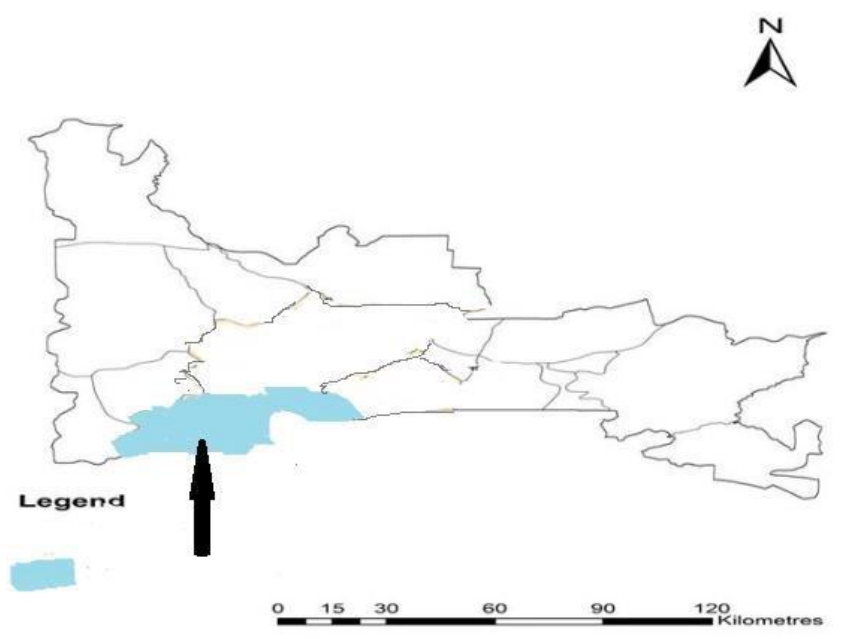

Figure 2: Map of Ogun State showing Ado-Odo Ota L.G.A 

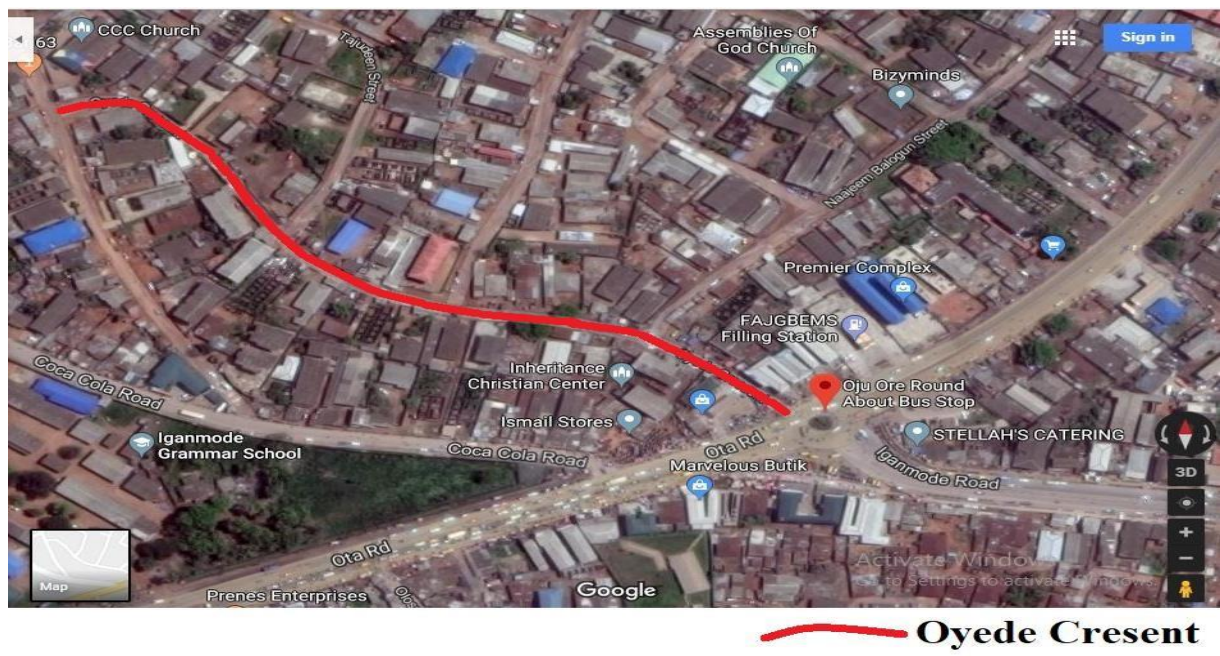

Figure 3: Satellite image of Oyede Crescent at Oju-Ore

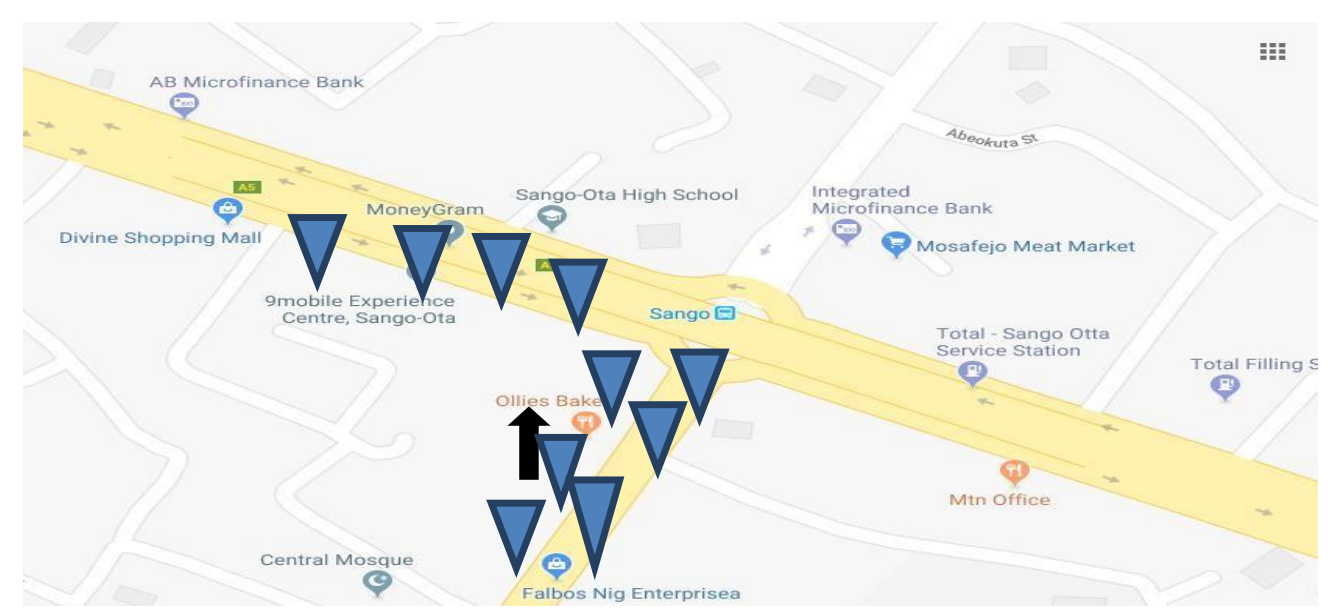

Figure 4: Map showing study locations

\subsection{Reconnaissance for a GPS survey}

Reconnaissance is one of the most important parts of a GPS survey. For the actual collection of GPS data, the observing station must have a clear view of the sky when satellites are passing over the job site. It involves site visit and selection of the best location for the control point.

\subsection{Data Source}

The sources of data employed for this research includes both secondary and primary data sources. The secondary data include information obtained from publications such as journals, official documents, previous research works as well as newspapers on the various occurrences of flood disasters and pertinent issues relating to the subject and the primary source of data were extracted from field survey, personal interviews and through questionnaires administration.

A structured questionnaire was prepared and administered to the residents residing in the flood prone area within the Ado-Odo Ota Local Government. Interview was conducted with selected respondents who were unable to fully comprehend and answer the questionnaire provided, while, field survey was done for inspection of some areas that are prone to flood so as to obtain direct information. The data collected were analyzed using chi square to examine the variation between independent and dependent variable.

\subsection{Data collection}

The data used in this study came from using GPS to acquire coordinates of points. The sample selection includes four areas, based on the locations of the areas, the areas were assessed one after the other for the survey process, and the questionnaires were collected and checked for the completeness and validity of collected questionnaires. Before each interview began, the purpose of the investigation 
and confidentiality principles were verbally explained by the investigators and practiced for perfection. The participation of the respondents in this study was voluntary and consented, and enough time was given. Any confusion of the questions during the survey was explained by the investigators and the respondents had the rights to refuse to participate or withdraw from the survey at any time. At least, 120 questionnaires were distributed, 110 were collected, and the number of valid responses after the subtraction of incomplete questionnaires was 100 (the response rate was $83.3 \%$ ).

\subsection{Sample selection}

Five areas were chosen as survey sampling locations that are event to flood. Sango, Oju- Ore, Joju, Ijoko and Abeokuta road are the urban centers of Ota in Ado-Odo Local Government. A questionnaire was designed to investigate the flood event areas. Respondents with different educational levels were included in the questionnaire, and their feedbacks on the details of the questionnaire were harvested. Based on these responses, the language used was simple and easy to understand. In the first part of the questionnaire, the purpose of the investigation and the relevant confidentiality principles were highlighted. This was used to inform respondents that the survey is anonymous with the data collected.

The main content of the questionnaire was divided into three main parts (Table 1). Each part had several objects for measurement. The first part included six items determining the most important socio-demographic factors of the respondents such as place of residence, gender, age, education level, occupation, and income per month (Kellens et al., 2013). The second section was other four important factors that could influence the flood event. The four impact factors were flood experience, flood knowledge education, flood protection responsibility, and believe in government. One impact factor consists one item. The third section was the measurement of public flood vent. The impact and likelihood are most often used variables to measure the flood event areas as the flood risk is usually defined by the product of the likelihood of flood disaster with its consequences (effects) (Kellens et al., 2013).

In this research some areas in Ota suffers from the flood almost every year. Therefore, the impact of the flood was more important to focus on.

Table 1: Definition of the measured and impact factors of flood prone areas

\begin{tabular}{|c|c|c|}
\hline Category & Description & Content \\
\hline Socio-demography & Characteristics respondents & $\begin{array}{l}\text { Areas } \\
\text { Genders } \\
\text { Age } \\
\text { Level of education } \\
\text { Occupation } \\
\text { Income per month }\end{array}$ \\
\hline \multirow[t]{4}{*}{ Other vital impact factors } & Flood experience by respondents & $\begin{array}{l}\text { The rate of experience respondents have on flood } \\
\text { disaster }\end{array}$ \\
\hline & Flood protection obligation & The obligation of flood protection agency \\
\hline & Flood education knowledge & $\begin{array}{l}\text { The knowledge about education that respondents have } \\
\text { on flood }\end{array}$ \\
\hline & Believe in government responsibility & $\begin{array}{l}\text { They believe of respondents in government on flood risk } \\
\text { management }\end{array}$ \\
\hline Flood risk events & Respondents perceived flood risk & The effect of flood disaster \\
\hline
\end{tabular}

\subsection{Data processing}

Quantitative and descriptive statistics were applied to reveal the features of the socio-demographic characteristics of the respondents and their impact factors like flood protection responsibility, flood knowledge education, flood experience, and trust in government. A statistical analysis was carried out under a significance test value of 0.05 to confirm whether these impact factors affected the flood Occurrence. Impact factors with the significance value of less than 0.05 were considered to be significantly influential to flood risk conception. 


\subsection{Results and Discussion}

In this research, 100 survey questionnaires were analyzed. These results were presented in tables containing data of responds and the subsequent analyses.

\subsection{Data analysis}

The Chi-square analysis was employed as the statistical too for this study. The results obtained from the analyses are presented in Table 2, for analyses from respondents based on flood occurrence, in Table 3, for analyses from respondents based on flood education awareness, and in Table 4, for analyses from respondents based on flood protection agencies.

Table 2: Chi square analysis for percentages and number of respondents on flood occurrence

\begin{tabular}{|c|c|c|c|c|c|}
\hline & \multicolumn{5}{|c|}{ Percentages and number of Respondents on Flood occurrence } \\
\hline & Oju-Ore & Sango & Joju & Total & \\
\hline \multirow{3}{*}{ Less than once in a year } & 2 & 3 & 5 & 10 & \\
\hline & 2.50 & 4.50 & 3.00 & 10.00 & 20 \\
\hline & $(0.10)$ & $(0.50)$ & $(1.33)$ & $(0.00)$ & \\
\hline \multirow[t]{3}{*}{ Once in a year } & 5 & 5 & 7 & 17 & \\
\hline & 4.25 & 7.65 & 5.10 & 17.00 & 34 \\
\hline & $(0.13)$ & $(0.92)$ & $(0.71)$ & 0.00 & \\
\hline \multirow[t]{3}{*}{ One or two times in a year } & 8 & 12 & 8 & 28 & \\
\hline & 7.00 & 12.60 & 8.40 & 28.00 & 56 \\
\hline & $(0.14)$ & $(0.03)$ & $(0.02)$ & $(0.00)$ & \\
\hline \multirow[t]{4}{*}{ More than two times in a year } & 10 & 25 & 10 & 45 & \\
\hline & 11.25 & 20.25 & 13.50 & 45.00 & 90 \\
\hline & $(0.14)$ & (1.11) & $(0.91)$ & $(0.00)$ & \\
\hline & 25 & 45 & 30 & 100 & 200 \\
\hline
\end{tabular}

$\chi 2=6.042 ; \mathrm{df}=9 ; \chi^{2} / \mathrm{df}=0.67 ; \mathrm{P}\left(\chi^{2}>6.042\right)=0.7357$

Where $\mathrm{df}=$ degree of freedom, $\chi^{2}=$ Test statistic, $\mathrm{P}=$ probability.

Table 3: Chi square analysis for percentages and number of respondents on flood education awareness

\begin{tabular}{|c|c|c|c|c|c|}
\hline & \multicolumn{5}{|c|}{ Percentages and number of respondents on flood education awareness } \\
\hline & Oju-Ore & Sango & Joju & Total & \\
\hline \multirow{3}{*}{ Never } & 10 & 22 & 13 & 48 & \\
\hline & 11.62 & 20.93 & 13.95 & 46.50 & 93 \\
\hline & $(0.23)$ & $(0.06)$ & $(0.06)$ & $(0.05)$ & \\
\hline \multirow[t]{3}{*}{ Few } & 7 & 13 & 7 & 24 & \\
\hline & 6.38 & 11.47 & 7.65 & 25.50 & 51 \\
\hline & $(0.06)$ & $(0.20)$ & $(0.06)$ & $(0.09)$ & \\
\hline \multirow[t]{3}{*}{ Medium } & 5 & 8 & 6 & 19 & \\
\hline & 4.75 & 8.55 & 5.70 & 19.00 & 38 \\
\hline & $(0.01)$ & $(0.04)$ & $(0.02)$ & $(0.00)$ & \\
\hline \multirow[t]{4}{*}{ High } & 3 & 2 & 4 & 9 & \\
\hline & 2.25 & 4.05 & 2.70 & 9.00 & 18 \\
\hline & $(0.25)$ & (1.04) & $(0.63)$ & $(0.00)$ & \\
\hline & 25 & 45 & 30 & 100 & 200 \\
\hline
\end{tabular}

$\chi^{2}=2.781 ; \mathrm{df}=9 ; \chi^{2} / \mathrm{df}=0.31 ; \mathrm{P}\left(\chi^{2}>2.781\right)=0.9724$ 
Table 4: Chi square analysis for percentages and number of respondents on flood protection agencies

\begin{tabular}{|c|c|c|c|c|c|}
\hline \multirow[t]{2}{*}{ Agencies } & \multicolumn{5}{|c|}{ Percentages and number of Respondents on Flood Protection } \\
\hline & Oju-Ore & Sango & Joju & Total & \\
\hline \multirow[t]{2}{*}{ Government } & 5 & 3 & 2 & 10 & \\
\hline & $\begin{array}{l}2.50 \\
(2.50)\end{array}$ & $\begin{array}{l}4.50 \\
(0.50)\end{array}$ & $\begin{array}{l}3.00 \\
(0.33)\end{array}$ & $\begin{array}{l}10.00 \\
(0.00)\end{array}$ & 20 \\
\hline \multirow[t]{3}{*}{ Flood protection management } & 5 & 11 & 6 & 22 & \\
\hline & 5.50 & 9.90 & 6.60 & 22.00 & 44 \\
\hline & $(0.05)$ & $(0.12)$ & $(0.05)$ & $(0.00)$ & \\
\hline \multirow[t]{3}{*}{ Company } & 10 & 20 & 13 & 43 & \\
\hline & 10.75 & 19.35 & 12.90 & 43.00 & 86 \\
\hline & $(0.05)$ & $(0.02)$ & 0.00 & $(0.00)$ & \\
\hline \multirow[t]{3}{*}{ Community } & 3 & 8 & 5 & 16 & \\
\hline & 4.00 & 7.20 & 4.80 & 16.00 & 32 \\
\hline & $(0.25)$ & $(0.09)$ & $(0.01)$ & $(0.00)$ & \\
\hline \multirow[t]{4}{*}{ General public } & 2 & 3 & 4 & 9 & \\
\hline & 2.25 & 4.05 & 2.70 & 9.00 & 18 \\
\hline & $(0.03)$ & $(0.27)$ & $(0.63)$ & $(0.00)$ & \\
\hline & 25 & 45 & 30 & 100 & 200 \\
\hline
\end{tabular}

$\chi^{2}=4.904 ; \mathrm{df}=12 ; \chi^{2} / \mathrm{df}=0.41 ; \mathrm{P}\left(\chi^{2}>4.904\right)=0.9611$

\subsection{Data presentation}

The data obtained from respondents were presented in Table 5. In this table, the summarized numbers of responses for each area are presented as well as the socio-demographic variables of the respondents. The data therefore shows that numbers of respondents in Sango area were higher, i.e. more responses were collected, than in the other areas for the study. Table 6 summarized the distribution of other vital impact factors (flood experience, flood knowledge education, flood protection responsibility, and believe in government). Table 7 shows the UTM coordinate systems of each location at the study area.

Table 5: Ages and standard of living of the respondents

\begin{tabular}{lllll}
\hline Variable & Ota area & Oju-Ore & Sango & Joju \\
\hline Total number of respondents & 100 & 25 & 45 & 30 \\
\hline Age & & & & \\
\hline $16-20$ & 12 & 2 & 8 & 3 \\
$21-40$ & 32 & 12 & 16 & 12 \\
$41-60$ & 33 & 5 & 12 & 9 \\
$61-70$ & 15 & 4 & 3 & 4 \\
70- above & 8 & 2 & 6 & 2 \\
\hline Educational level & & & & \\
\hline Primary school and below & 16 & 2 & 8 & 9 \\
Middle school & 33 & 8 & 12 & 9 \\
High school Middle school & 37 & 11 & 18 & 8 \\
Bachelor & 8 & 3 & 2 & 2 \\
Master and above & 6 & 1 & 5 & 2 \\
\hline Occupation & & & & \\
\hline Government work & 15 & 3 & 5 & 4 \\
Company work & 31 & 6 & 8 & 6 \\
Self-employed & 35 & 9 & 18 & 10 \\
Students & 11 & 4 & 7 & 4 \\
Retired person & 5 & 2 & 4 & 4 \\
Others & 3 & 1 & 3 & 2 \\
\hline Income per month/ naira & & & & \\
\hline 0-20,000 & 30 & 8 & 11 & 6 \\
21,000-50,000 & 53 & 11 & 19 & 13 \\
51,000-100,000 & 10 & 4 & 10 & 9 \\
100,000 above & 7 & 2 & 5 & 2 \\
\hline & & & & \\
\hline
\end{tabular}


Table 6: Percentages and number of respondents on flood occurrence

\begin{tabular}{lllll}
\hline Location (Ota area) & Oju-Ore & Sango & Joju & Total (100)\% \\
\hline Number of respondents (\%) & 25 & 45 & 30 & 100 \\
\hline Flood experience (\%) & & & & \\
\hline Less than once in a year & 2 & 3 & 5 & 10 \\
Once in a year & 5 & 5 & 7 & 17 \\
One or two times in a year & 8 & 12 & 8 & 28 \\
More than two times in a year & 10 & 25 & 10 & 45 \\
\hline Flood education awareness (\%) & & & & \\
\hline Never & 10 & 22 & 13 & 48 \\
Few & 7 & 13 & 7 & 24 \\
Medium & 5 & 8 & 6 & 19 \\
High & 3 & 2 & 4 & 9 \\
\hline Flood protection agency (\%) & & & & \\
Government & 5 & 3 & 2 & 10 \\
Flood protection management & 5 & 11 & 6 & 22 \\
Company & 10 & 20 & 13 & 43 \\
Community & 3 & 8 & 5 & 16 \\
General public & 2 & 3 & 4 & 9 \\
\hline
\end{tabular}

Table 7: UTM coordinate system

\begin{tabular}{|c|c|c|c|}
\hline Location & Northing $(\mathrm{mN})$ & Easting $(\mathrm{mE})$ & Height $(\mathrm{m})$ \\
\hline \multicolumn{4}{|l|}{ Oju-Ore } \\
\hline 1 & 739300.49 & 525279.92 & 69.4 \\
\hline 2 & 739301.81 & 525281.02 & 69.2 \\
\hline 3 & 739310.11 & 525282.13 & 69.0 \\
\hline 4 & 739323.70 & 525281.01 & 67.8 \\
\hline 5 & 739324.14 & 525279.91 & 68.4 \\
\hline 6 & 739337.41 & 525270.51 & 68.6 \\
\hline 7 & 739351.56 & 525272.05 & 70.7 \\
\hline 8 & 739372.88 & 525257.34 & 68.3 \\
\hline 9 & 739384.15 & 525246.50 & 68.6 \\
\hline 10 & 739399.96 & 525232.35 & 68.1 \\
\hline \multicolumn{4}{|l|}{ Sango } \\
\hline 1 & 741610.73 & 526317.72 & 79.1 \\
\hline 2 & 741600.79 & 526337.62 & 73.3 \\
\hline 3 & 741593.17 & 526358.62 & 73.4 \\
\hline 4 & 741582.01 & 526370.79 & 76.4 \\
\hline 5 & 741561.03 & 526418.65 & 75.1 \\
\hline 6 & 741540.05 & 526457.12 & 74.0 \\
\hline 7 & 741494.22 & 526564.24 & 76.6 \\
\hline 8 & 741479.64 & 526589.66 & 75.8 \\
\hline 9 & 741462.76 & 526640.51 & 77.0 \\
\hline 10 & 741445.52 & 526664.61 & 79.4 \\
\hline \multicolumn{4}{|l|}{ Joju } \\
\hline 1 & 741331.62 & 526800.39 & 72.3 \\
\hline 2 & 741318.35 & 526795.31 & 73.6 \\
\hline 3 & 741306.30 & 526794.87 & 72.5 \\
\hline 4 & 741289.27 & 526782.06 & 78.1 \\
\hline 5 & 741282.63 & 526781.29 & 78.6 \\
\hline 6 & 741274.34 & 526773.34 & 78.5 \\
\hline 7 & 741254.55 & 526766.72 & 77.3 \\
\hline 8 & 741247.25 & 526759.98 & 79.1 \\
\hline 9 & 741235.42 & 526751.14 & 78.9 \\
\hline 10 & 741206.45 & 526740.10 & 74.9 \\
\hline
\end{tabular}

As illustrated in Table 6, higher respondents confirmed that flood occurs more than once in a year (45\%) in the study area, also a larger number (48\%) lacks flood education while only few (9\%) respondents have education on flood. A larger response shows the availability of agency responsible for flood protection are private organization like company that is $(43 \%)$ while $(10 \%)$ is from government. 


\subsection{Flood induced by man's activities}

The result of the questionnaire given on the causes of flood revealed that a large portion of the respondents believed that man induced activities resulted in $40 \%$ of flooding due to dumping of waste material and refuse into water channels while (27\%) of the respondent confirmed that it is caused by non-functional drainage. A high proportion of respondents, (10\%) perceived that flood is caused by overflowing of water bodies. While a lesser proportion $(8 \%)$ perceived that the cause of flood is the encroachment of buildings on the flood plain, about (15\%) are functional. This study is an indication that a lot of human attitudes has contributed immensely to flood occurrence in the study area (Table 8).

Table 8: Causes of flood in the study area

\begin{tabular}{ll}
\hline Causes of flood & Percentage (\%) \\
\hline Functional Drainage & 15 \\
Non -Functional Drainage & 27 \\
Overflow of Water Bodies & 10 \\
Encroachment of Building to Floodplain & 8 \\
Indiscriminate Dump of Waste into Water channel & 40 \\
\hline
\end{tabular}

\subsection{Conclusion}

Water will always find its own path if not properly channelled by man. The need to study the flood prone areas and causes of causes of flood and provide adequate flood management strategies is an aspect of surveying and Geo-informatics that surveyors must pay good attention to. The improvement of roads for accessibility in cities, provision of funds and equipment for disaster management agencies is vital in prevention of disasters in the Nigerian urban environment and even in the rural areas. In both the developed and developing world, the problems associated with flooding constitute a growing hazard to human activities as population densities increase.

Based on the assessment in different areas, which show that, a hundred percent (100\%) success could not totally be achieved in elimination of flood problems especially in urban environment, but their negative effects can be mitigated through proper management measures given by government or affected communities. These must be effectively and economically supervised and supported.

This study was able to discover the causes of flood in Ota at different locations and the possible solutions to prevent future occurrence of flood.

Based on the findings of this study, there are some recommendations that are possible solutions that would allow immediate remedial and preventive measures to reduce flood problems observed in the study area. Therefore, the following measures are recommended:

1. There is a need for provision of standard infrastructural facilities by the government. These facilities include good surface drainage, potable water supply for consumption and other supporting facilities

2. Repair and construction of drainages where necessary should be embarked on to further ease the flow of storm water. And excavation of solid waste and other deposits which are present in the existing drainage

3. Environmental sanitation program must be made compulsory and appropriate agency should be vested with the power to punish residents who fail to adhere to the rule of sanitation. There should be fines and penalties for people who fail to comply with the sanitation program

4. Adequate awareness and orientation should be given to people on the dangers of dumping refuse in the drains and the damaging effect of such actions to the community.

\section{References}

Adeaga, O. (2008). Flood Hazard Mapping and Risk Management in Parts of Lagos N. E., Department of Geography, University of Lagos, Akoka, Lagos, Nigeria.

Etinosa, U. (2006). "Dams Are Unrenewable". A Discussion Paper" (PDF). Community Research and Development Centre. Retrieved 2010-05-21 
European Union (EU) Flood Directive (2007). Directive 2007/60/EC of the European Parliament and of the Council of 23 October 2007 on the assessment and management of flood risks. European Union (EU).

Kellens, W., Terpstra, T. and De Maeyer, P. (2013). Perception and communication of flood risks: a systematic review of empirical research. Risk Analysis, 33(1), pp. 24-49.

Odunuga, S., Oyebande, L., and Omojola, S. (2012). The influence of precipitation and land use change on flood incidence in Lagos Metropoilis, Nigeria. Nigerian Journal of Hydrological Sciences, NJHS, 1, pp. 1-17.

Olajuyigbe, A. E., Rotowa, O. O. and Durojaye, E. (2012) An Assessment of Flood Hazard in Nigeria: The Case of Mile 12, Lagos. Mediterranean Journal of Social Sciences, Department of Urban and Regional Planning, Federal University of Technology, Akure, 3, pp. 367-375.

Olaniran, O.J. (1983). The Onset of the Rains and the Start of the Growing Season in Nigeria. Nigerian Geographical Journal, 26, pp. 81-88.

Petak, W. J. and Atkisson, A. A. (1982). Book review: Natural hazard risk assessment and public policy: anticipating the unexpected. New York: Springer

Sharma, R.K. and Sharma, T.K. (2000). A Textbook of Hydrology and Water Resources Engineering. Dhanpat Rai Publications.

\section{Cite this article as:}

Oseni A. E. and Bamidele E. T., 2020. The Contributing Effects of Human Activities to Flooding in Ota, Ogun State. Nigerian Journal of Environmental Sciences and Technology, 4(1), pp. 204-213. https://doi.org/10.36263/nijest.2020.01.0195 